\title{
Antimicrobial Effect of Anacardium Occidentale Extract and Cosmetic Formulation Development
}

\author{
Gisele Mara Silva Gonçalves * and Juliana Gobbo \\ Faculdade de Ciências Farmacêuticas; Pontifícia Universidade Católica de Campinas; Campinas - SP - Brasil
}

\begin{abstract}
The objective of this work was to assess the activity of the extract of Anacardium occidentale Staphylococcus epidermidis and $\mathrm{S}$. aureus and then to develop cosmetic formulations from those extracts. These formulations were stable in relation to their $\mathrm{pH}$ and rheological behavior, but were gradually darkened when stored for assessment at temperatures between 40 and $60^{\circ} \mathrm{C}$. Thus, even though the extract appeared a promising raw material for use in cosmetic formulations, those compounds might still require adjustments to improve the stability.
\end{abstract}

Key words: Anacardium occidentale L., Antimicrobial, Cosmetic, Extract, Rheology

\section{INTRODUCTION}

The plant Anacardium occidentale L. belongs to the Anacardiaceae family and is indigenous to tropical regions such as Northeast Brazil. Its fruit, popularly known as the cashew, consists of two parts: the fruit itself (the nut), and the accessory fruit (or flower stalk), also known as the cashew apple (Alcântara et al. 2009, Assunção et al. 2003). The cashew apple contains tannins, vitamin $\mathrm{C}$, sugars, carotenoids, organic acids, proteins, fibers, and water (Queiroz et al. 2011). Tannins are widely used in the leather industry for transforming the skins of animals into finished leather. Tannins are also important gustatory components responsible for the astringency of many fruits and vegetables, including the cashew. In addition to their pharmacological activities (Santos and Mello 2003), the compounds formed between tannins and proteins are the bases for their insecticidal, antifungal, and antibacterial properties.
There are several reports on the pharmacological activities of cashew tree byproducts, such as antiinflammatory and antidiabetic agents, as well as acetylcholinesterase inhibitors. Further, substances derived from the cashew fruit have also proven to be tyrosinase inhibitive. Chaves et al. (2010) found that ethanol extracts, especially those from the $A$. occidentale stalk, could be used both as a food additive as well as an ingredient in pharmaceutical preparations designed to replace the synthetic antioxidants.

In vitro tests done with tannin-containing extracts have demonstrated that such compounds have diverse antibacterial and antifungal activities. The pharmacological activities of tannins are likely to be the result of three factors: complexation with metal ions, antioxidant activity and free-radical scavenger. Tannins are also capable of combining with other types of molecules, including macromolecules such as proteins and polysaccharides (Santos and Mello 2003). The anticarcinogenic and antimutagenic potentials of tannins may be related to their antioxidative

*Author for correspondence: gmsg@puc-campinas.edu.br 
property, which is important in protecting the cellular oxidative damage, including lipid peroxidaton (Chung et al. 1998).

Acne is a skin condition common in adolescents. This problem can adversely affect the young adults and, if not treated properly, might even persist for long periods of time. Depending upon the patient and the causal factors, a cure is not easy to achieve and treatment is likely to be lengthy. Thus, treatment success may depend upon the patient's persistence and collaboration with medical professionals (Sinclair and Jordaan 2005).

Products for acne are designed to reduce the sebum secretion or control the proliferation of microorganisms. Such products, if effective, should also maintain the natural $\mathrm{pH}$ of the skin, should moisturize, and (since excess exposure to sunlight can cause thickening of the skin's corneal layer) should provide protection against the solar radiation. Such corneal thickening, if not deterred, might cause an obstruction of the pilosebaceous follicle, thereby promoting an onset of acne (Leonardi et al. 2004).

Although the microorganism, Propionibacterium acnes, is commonly believed to be the cause of acne vulgaris, other microorganisms are also found on the skin. Examples of such microorganisms are Staphylococcus epidermidis (the most commonly isolated microorganism from skin microbiota) and S. aureus, which may cause a number of different skin infections, including folliculitis (Cogen et al. 2008).

Microbial resistance has been observed by many health professionals, including dermatologists. It has also been found that one of the risks associated with the use of antibiotics is the unintended development of allergies -- as has been observed with bacitracin and neomycin (Draelos et al. 2010). To overcome this issue of antibiotic resistance, medicinal plants have been extensively studied as alternative treatments for various diseases (Vijayalakshmi et al. 2011).

Thus, to improve the quality of life for people affected by acne (since acne tends to affect selfesteem), it becomes increasingly necessary to search for active substances that have both antimicrobial and astringent activities - such as the tannins found in the extracts of many fruits and vegetables.

The objective of the present study was to expand this search by obtaining an extract of the Anacardium occidentale apple, to test it for tannins, and then to incorporate this extract into cosmetic formulations for the skin. Attempts were alos made to determine their physical and physical-chemical stabilities by assessing their rheological behavior and organoleptic characteristics over time, thereby verifying the antimicrobial efficacy of the extract against $S$. epidermidis and S. aureus.

\section{MATERIALS AND METHODS}

\section{A. occidentale extracts}

The extracts were prepared from unpeeled, ripe cashew apples that were soaked in a $0.5 \%$ sodium hypochlorite solution for 30 minutes and then washed in distilled water. They were then blended in a homogenizer with the appropriate extraction liquid and macerated as described below. The extraction liquids for extract I and II were acetone and water (1:1), or ethanol and water (1:1), respectively.

All the glassware used was sterilized. After one minute in the homogenizer, the mixture was allowed to rest for one hour. This procedure was repeated twice. After the third homogenization (and while protecting the process from light), the mixture was drained and filtered with a very fine nylon sieve to prevent the tannins from being absorbed by a paper filtering method. Once the extract was ready, a rotary evaporator was used to remove as much of the acetone as possible at $40^{\circ} \mathrm{C}$ and a negative pressure of $-600 \mathrm{mmHg}$ (AgostiniCosta et al.2003). At the end of the procedure, the extracts were placed in sterile amber glass flasks, sealed with parafilm, and then stored under refrigerated conditions.

\section{Testing for tannins}

Two tests were used for tannins: (1) the iron salts test, in which four drops of $1 \%$ ferric alum were added to $2.0 \mathrm{~mL}$ of the extract, diluted in $2.0 \mathrm{~mL}$ of distilled water. If tannins were present, a black precipitate would form; (2) the lead acetate test, in which $10 \mathrm{~mL}$ of $10 \%$ acetic acid and $5.0 \mathrm{ml}$ of $10 \%$ lead acetate were added to $5.0 \mathrm{~mL}$ of the extract. A white precipitate would form if tannins were present (Santos and Melo 2003).

\section{Antimicrobial action of extracts}

A broth dilution method was employed based upon a process suggested by Kalemba and Kunicka (2003), but with some modifications. Five milliliters of brain heart infusion (BHI) broth were 
added to $100 \mu \mathrm{L}$ of suspended inoculant ( $S$. epidermidis ATCC 12228 or Staphylococcus aureus ATCC 25923). The turbidity of this mixture was adjusted to 0.5 on the McFarland scale, and then $250 \mu \mathrm{L}$ of one of the samples was added to a sterile test tube.

The samples consisted of $0.5 \%$ triclosan in ethanol, $50 \%$ acetone in water (for acetone control), $50 \%$ ethanol in water (ethanol control), and $A$. occidentale extracts (extract I and II, respectively), diluted to $70,50,30$, and $10 \%$ in water (volume/volume). Undiluted extract I and II were also inoculated and added in different volumes to the tubes: $0.5,1.0$ and $3.0 \mathrm{~mL}(9.09$, 16.66 and $37.49 \%$, respectively). All the experiments were repeated three times.

Microbial growth was indicated if turbidity was detected after incubation at $37^{\circ} \mathrm{C}$ for $24 \mathrm{~h}$. If the broth became turbid when the sample was added, the test tube was then incubated and a sample was taken to inoculate another tube containing only BHI broth. Finally, the last tube was then incubated and, after this incubation period, any observed presence of turbidity was deemed to be microbial growth.

\section{Extract added to cosmetic skin-care vehicles}

Only extract II obtained with ethanol was used in the formulations. Gels and gel creams were prepared to select the best vehicle for the extract (Table 1). For each formulation (gel or gel cream), two final formulations were prepared: with or without $5 \%(\mathrm{w} / \mathrm{w})$ extract II (for the purposes of comparison). All the components of the formulations were denominated according to the International Nomenclature of Cosmetic Ingredients (INCI).

Table 1 - Components of the formulations under study.

\begin{tabular}{|c|c|c|c|c|c|}
\hline \multicolumn{6}{|l|}{ Formulations } \\
\hline \multirow[t]{2}{*}{ Components (INCI) } & \multicolumn{5}{|c|}{$\begin{array}{l}\text { Percentage of components in each } \\
\text { formulation }\end{array}$} \\
\hline & A & B & C & D & $\mathbf{E}$ \\
\hline Ammonium Acryloyldimethyltaurate / VP Copolymer & 2.0 & - & - & - & - \\
\hline Acrylate polymer containing carboxyl groups & - & 3.0 & - & - & 2.0 \\
\hline Hydroxyethyl cellulose & - & - & 2.0 & 2.0 & - \\
\hline Batyl Alcohol, Stearic Acid, Lecithin, Caprylic/Capric Triglyceride & - & - & - & 2.0 & - \\
\hline Propylene Glycol & 5.0 & 5.0 & 5.0 & 5.0 & 5.0 \\
\hline Triethanolamine & s.a. & s.a. & s.a. & s.a. & s.a. \\
\hline $\begin{array}{l}\text { Phenoxyethanol, Methylparaben, Ethylparaben, Propylparaben, } \\
\text { Butylparaben, Isobutylparaben }\end{array}$ & 0.6 & 0.6 & 0.6 & 0.6 & 0.8 \\
\hline Disodium EDTA & 0.2 & 0.2 & 0.2 & 0.2 & 0.2 \\
\hline Distilled water & 87.0 & 86.0 & 87.0 & 85.0 & 86.8 \\
\hline
\end{tabular}

INCI, International Nomenclature of Cosmetic Ingredients

s.a. sufficient amount to $\mathrm{pH} 6.0$ to 6.5 approximately.

\section{RESULTS AND DISCUSSION}

Unripe A. occidentale apples were considered most desirable to be used for this study because of their higher tannin content (Agostini-Costa et al. 2002). The selection of the optimal extracting solvent was based upon work by Agostini-Costa et al. (2002), who examined a wide variety of parameters for optimizing tannin extraction from cashew apples. They found that $50-70 \%$ acetone mixture extracted the maximum amount of tannin from cashew apples. Hence, acetone was the starting solvent in the present study. However, since ethanol has been considered safer for topical application, acetone was later replaced by ethanol to better allow the extract to be used in this manner. The extract I and II contained 19.32 and $18.46 \mathrm{mg} / \mathrm{ml}$ tannins, respectively. These concentrations were nearly similar, thereby allowing the small difference to be disregarded.

The results of the first step of the microbiological studies were contiguous with regard to the positive controls, negative controls (no microbial growth detected), and acetone and ethanol microbial growth occurred indicating that neither acetone nor ethanol had interfered with the microbial development). However, none of the extracts in the concentrations initially used were capable of 
preventing the growth of microbes. For this reason, the amount of extract added to the test tubes containing the inoculant and culture medium was increased. The solutions using higher $A$. occidentale concentrations were then capable of inhibiting the microbial growth, as shown in Table 2 , and the highest concentration $(37.49 \%)$ of the three tubes inhibited growth of all the studied microorganisms, represented by the negative sign (-). Extract I also inhibited S. epidermidis growth when used at $16.66 \%$, thereby indicating that this microorganism was the more sensitive.
When growth occurred in only one of the tubes represented by two negative signs and one positive sign as shown in Table 2, the microorganism was considered resistant. Thus, the results indicated that the extracts inhibited $S$. epidermidis growth. In relation to $S$. aureus, only the extract obtained with acetone was effective when used in the highest concentration. The difference between the extracts could be associated with the amount of antimicrobial substances extracted from $A$. occidentale apples using the different solvents.

Table 2 - S. epidermidis and $S$. aureus growth in the presence of different concentrations of Anacardium occidentale extract obtained with acetone (Extract I) or ethanol (Extract II). Triplicate.

\begin{tabular}{cccc}
\hline Sample & Concentration $(\% \mathbf{\%} / \mathbf{v})$ & S. epidermidis & S. aureus \\
\hline Extract I & $9.09 \%$ & $(-)(-)(+)$ & $(-)(+)(+)$ \\
& $16.66 \%$ & $(-)(-)(-)$ & $(-)(+)(+)$ \\
& $37.49 \%$ & $(-)(-)(-)$ & $(-)(-)(-)$ \\
Extract II & $9.09 \%$ & $(-)(-)(+)$ & $(-)(-)(+)$ \\
& $16.66 \%$ & $(-)(-)(+)$ & $(+)(+)(+)$ \\
& $37.49 \%$ & $(-)(-)(-)$ & $(-)(-)(+)$
\end{tabular}

(+) presence of growth; (-) absence of growth.

Silva et al. (2007) assessed the effect of a cashew tree bark water/alcohol extract on $S$. aureus (resistant and sensitive to methicillin) and found it to be effective against all the samples. This result suggested its effective use for the strains resistant to other antibiotics. Thus, it was clear that other parts of the plant contained substances with antimicrobial properties similar to that of the cashew. Other authors found that cashew tree bark extract revealed antimicrobial activity against $S$. mutans, $S$. mitis, and $S$. sanguis, thereby suggesting its therapeutic use in dentistry as an antibacterial agent (Melo et al 2006). According to Chermahini and Majid (2011), plants are important in formulating the natural and non-chemical cosmetic products. In their study, cashew leaves have shown both antioxidant and antimicrobial activities.

With regard to antimicrobial efficiency, the acetone extract was superior. The ethanol extract would be preferred for topical use, since its formulations would be safer. However, to optimize its effectiveness, it would be necessary to either improve the extraction method and/or to use a more concentrated solution of the extract.

Several authors have studied the antimicrobial effects of the extracts derived from different parts of this tree. Aiswarya et al. (2011) studied potential antimicrobial activity of cashew apple extracts obtained by using reflux and showed the inhibitory effect on the growth of Bacillus cereus and Klebsiella pneumoniae by virtue of a diffusion technique. Regarding the effect of extracts prepared before maturation, it was noted that an increase in the degree of tannin polymerization during maturation made them less reactive (Fiqueiredo et al. 2002).

The amount of tannin contained in a given plant can vary depending upon geographical and climatic conditions. Further, the kind and content of tannins also may vary from one plant to another as well as between different parts of the same plant (Battestin et al. 2004). An example that could illustrate this was an extract from the leaves of cashew that showed positive results for inhibition of $S$. aureus, Candida albicans, $P$. aeruginosa, and $S$. aureus. The minimum inhibitory concentration (MIC) was $15.62 \mathrm{mg} / \mathrm{ml}$ for ethanolic extract for $S$. aureus (Dahake et al. 2009). Pereira et al. (2006) reported that the extract from cashew tree stems showed a potential inhibitory action in the synthesis of glucan measured by the adherence to glass under sub-inhibitory conditions. The results suggested that the materials from the cashew tree 
could have some therapeutic uses in dentistry as an oral antibacterial agent.

The formulations without extract maintained the same $\mathrm{pH}$, color, odor, and aspect during the study period but the formulations containing the extract showed some variations (Tables 3 and 4). Although the formulations did not differ regarding some characteristics deemed important for the users (such as the quality of spreadability, whitening of skin during application, or stickiness), the most stable formulation in terms of $\mathrm{pH}$ was formulation $\mathrm{E}$. The cosmetic skin formulations were initially white or colorless (Table 3), and adding the extract did not change their color. After 28 days of storage at $60^{\circ} \mathrm{C}$, only formulations $\mathrm{C}$ and $\mathrm{D}$ exhibited some change in viscosity. The initial $\mathrm{pH}$ values (Table 4) were approximately 6.0 , or at a level which was appropriate for topical use. After the storage period at $60^{\circ} \mathrm{C}$, there was a small decrease in $\mathrm{pH}$, thereby indicating that heat promoted a decomposition of the product.

The smallest $\mathrm{pH}$ change was observed in formulation $\mathrm{E}$, which was prepared from formulation B using slightly less polymer to improve its sensory properties. Although formulation E, containing extract, was the most stable in terms of its $\mathrm{pH}$ and reaction to storage temperatures, it was still possible to observe its gradual darkening and a change in odor (Table 5).

According to Queiroz et al. (2011), cashew apple contained five times more vitamin $\mathrm{C}$ than an orange. Considering that this vitamin was water soluble, it could be suggested that the extract might also contain this substance and could lose stability as a consequence of being processed (Gonçalves and Maia Campos 2009). The reaction kinetics during the heat treatments, in general, is by first-order reactions (Lima et al. 2010), i.e., the higher the concentration, the faster degradation occurs. Other substances that may be contained in the extract and that may also have effects on the skin are quercetin and myricetin (HoffmannRibani et al. 2009).

The formulation stored at room temperature (Table 5) darkened slightly and crusts began to form by the seventh day of storage. The formulations stored at $40^{\circ} \mathrm{C}$ and $60^{\circ} \mathrm{C}$ presented the same changes which became more pronounced as the temperature and time increased. All the formulations presented crusts. The materials stored at 40 and $60^{\circ} \mathrm{C}$ presented dark crusts, strong odor, as well as a dried surface. These changes could be the result of oxidation. It was possible that the addition of antioxidant agents might lessen these changes, as discussed by Souza and Ferreira (2010), who assessed the stability of creams and gels with grape marc and found that samples stored at $45^{\circ} \mathrm{C}$ presented organoleptic changes and surface hardening, but no $\mathrm{pH}$ changes after the $15^{\text {th }}$ day. The authors suggested that stability could be improved by adding antioxidant agents to the formulations.

Crusts were also formed on the surface of the products and might well have been the result of a drying of the formula. Such changes indicated that the extract affected the stability of the product.

Table 3 - Spreadability, feel on the skin, skin whitening, odor and color of formulations A-E containing Anacardium occidentale extract.

\begin{tabular}{cccc}
\hline Product & Spreadability & Whitening of the skin & Color \\
\hline A & +++ & No & Colorless \\
B & ++ & No & Colorless \\
C & +++ & No & Colorless \\
D & - & Little & White \\
E & ++ & No & Colorless \\
\hline
\end{tabular}

(+++) Excelent, (++) Good, (-) Difficult, (S) Stick, (VS), Very stick, (SS) Slightly sticky.

Table 4 - pH of the formulations containing Anacardium occidentale extract before and after 28 days of storage at $60^{\circ} \mathrm{C}$

\begin{tabular}{|c|c|c|}
\hline \multirow{2}{*}{ Product } & \multicolumn{2}{|c|}{$\mathrm{pH}$} \\
\hline & Initial & After 28 days at $60^{\circ} \mathrm{C}$ \\
\hline A & 6.6 & 5.9 \\
\hline $\mathrm{B}$ & 5.3 & 5.4 \\
\hline $\mathrm{C}$ & 6.8 & 5.6 \\
\hline $\mathrm{D}$ & 6.4 & 5.5 \\
\hline $\mathrm{E}$ & 6.2 & 6.2 \\
\hline
\end{tabular}


Table 5 - Organoleptic characteristics of formulation "E" containing or not Anacardium occidentale extract over a 28-day period under room temperature, $40^{\circ} \mathrm{C}$ and $60^{\circ} \mathrm{C}$.

\begin{tabular}{ccccccc}
\hline Time & \multicolumn{2}{c}{ Vehicle } & \multicolumn{3}{c}{ Formulation added to Anacardium occidentale extract } \\
\hline & Room temperature & $40^{\circ} \mathrm{C}$ & $60^{\circ} \mathrm{C}$ & Room temperature & $40^{\circ} \mathrm{C}$ & $60^{\circ} \mathrm{C}$ \\
\hline 7 & $\mathrm{U}$ & $\mathrm{U}$ & $\mathrm{U}$ & $\mathrm{LM}$ & $\mathrm{LM}$ & $\mathrm{M}$ \\
14 & $\mathrm{U}$ & $\mathrm{U}$ & $\mathrm{U}$ & $\mathrm{LM}$ & $\mathrm{M}$ & $\mathrm{M}$ \\
19 & $\mathrm{U}$ & $\mathrm{U}$ & $\mathrm{U}$ & $\mathrm{LM}$ & $\mathrm{M}$ & $\mathrm{HM}$ \\
28 & $\mathrm{U}$ & $\mathrm{U}$ & $\mathrm{LM}$ & $\mathrm{LM}$ & $\mathrm{M}$ & $\mathrm{HM}$ \\
\hline
\end{tabular}

M: modified; LM: lightly modified; HM: highly modified; U: unchanged.

The rheological study (Figures 1 and 2) showed that all the formulations presented pseudoplastic behavior -- that is, their viscosity decreased as shear stress increased. The differences observed in the increasing (Series 1) and decreasing (Series 2) shear stress curves were similar and expected, since the formulation was pseudoplastic. However, some drying occurred in the formulations stored at $60^{\circ} \mathrm{C}$. This loss of moisture increased the concentration of the thickening agent, thereby impairing the rheological analysis. For this reason, only two shear stress readings were possible for the samples stored at $60^{\circ} \mathrm{C}$. In fact, this temperature was too high, suggesting that perhaps the results should be disregarded.

The rheograms showed that the curves remained closely similar to the baseline curves, indicating that the physical stability of the formulations did

a)

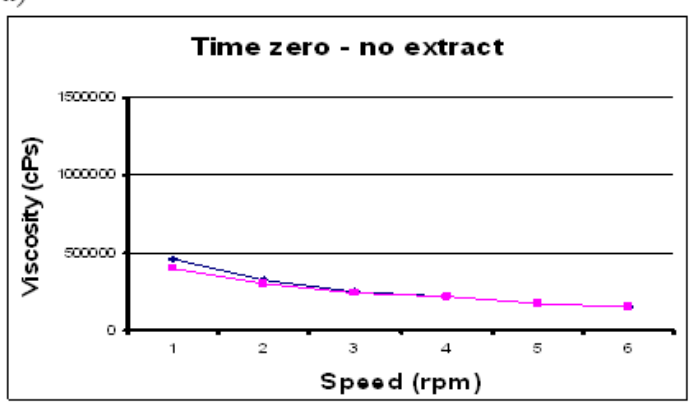

b)

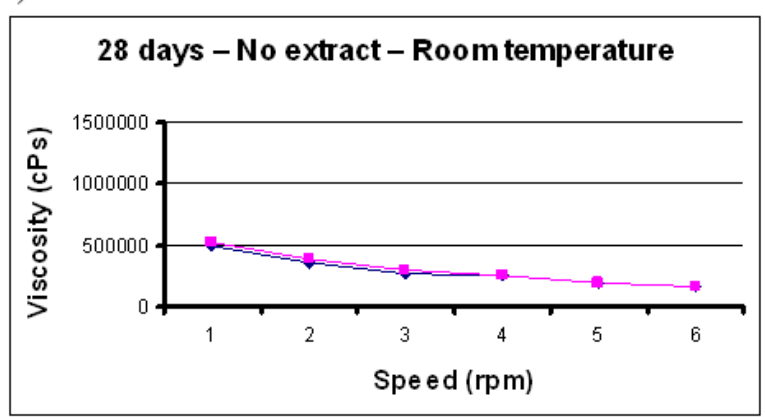

not change. The graphs did not contain any peaks, implying there were no points of instability (Gonçalves and Maia Campos 2009). In other words, the formulations were rheologically stable. These results were in agreement with those found by Correa et al. (2005) who studied the rheological behavior of different hydrophilic gels over varying storage times and with varied temperatures and found pseudoplastic behavior in those samples that were dependent upon storage temperature. Pseudoplastic behavior favors topical use because it improves the spreadability on the skin and, since formulations tend to recover their initial viscosity once rubbing stops, is less likely to drip. Additionally, the formulations did not present significant variations during the study and might therefore be considered rheologically stable.

c)

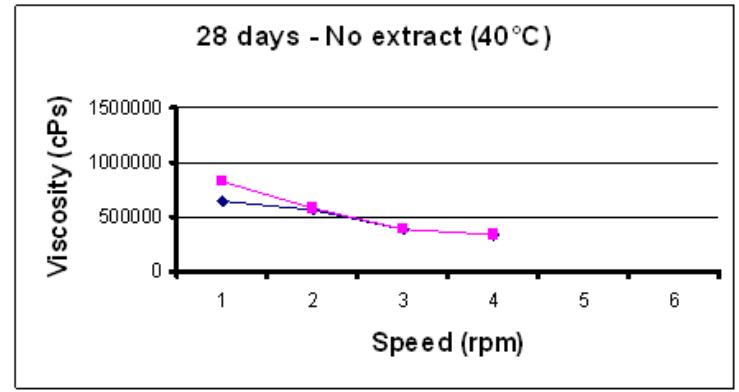

d)

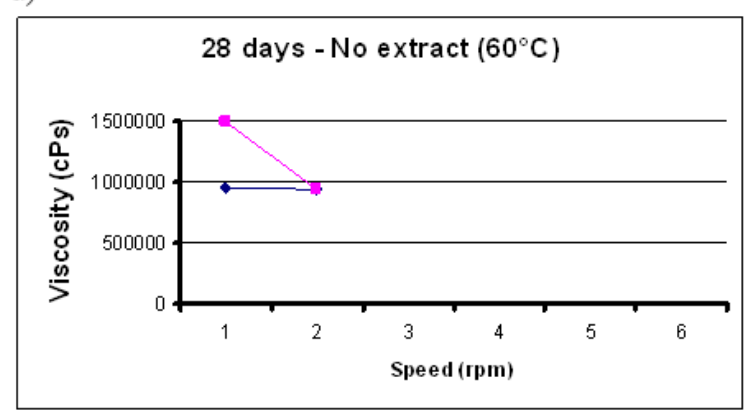

Figure1 - Apparent viscosity of the vehicle of the formulation $\mathrm{E}$ (which contained no extract), initial values (a) and stored at room temperature (b), $40^{\circ} \mathrm{C} \mathrm{(c)} \mathrm{and} 60^{\circ} \mathrm{C}(\mathrm{d})$ for 28 days. 
Series 1 (blue): increasing shear stress (0.5 to $5.0 \mathrm{rpm})$, Series 2 (pink): decreasing shear stress (5.0 to $0.5 \mathrm{rpm})$.

a)

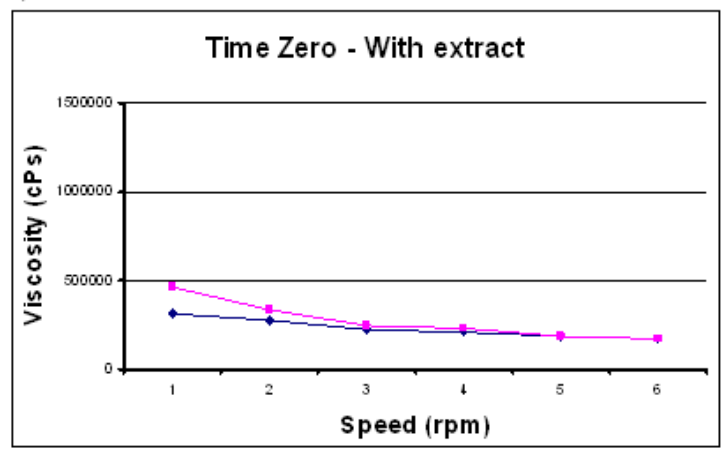

b)

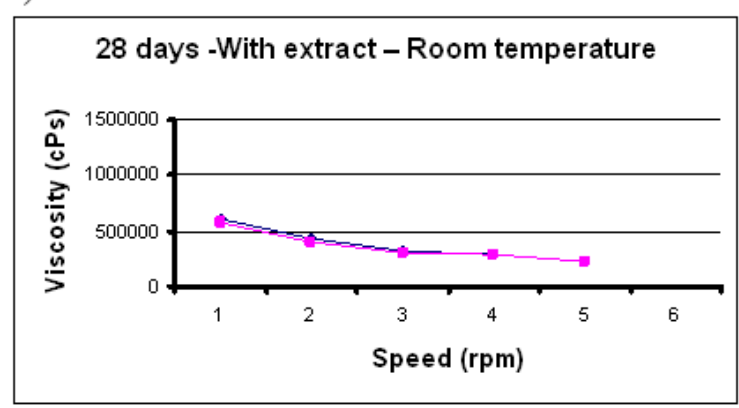

c)

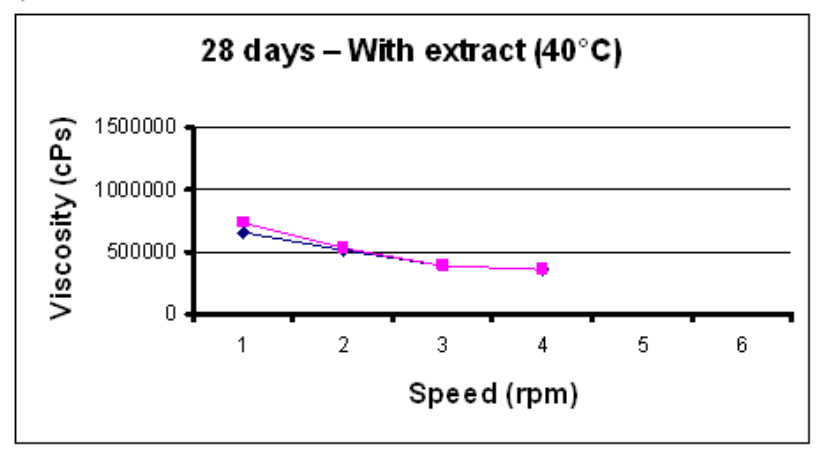

d)

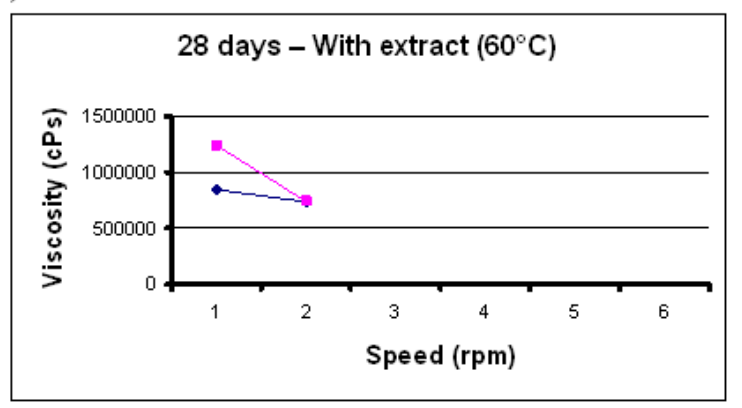

Figure 2 - Apparent viscosity of formulation E with Anacardium occidentale extract, initial values (a) and stored at room temperature (b), $40^{\circ} \mathrm{C}$ (c) and $60^{\circ} \mathrm{C}$ (d) for 28 days. Series 1 (blue): increasing shear stress (0.5 to $5.0 \mathrm{rpm}$ ), Series 2 (pink): decreasing shear stress (5.0 to $0.5 \mathrm{rpm}$ ).

To summarize, after preliminary studies, two extracts were obtained from $A$. occidentale apples (unripe, unpeeled, cashew), both of which tested positive for the tannins. The best extraction method employed the use of acetone (extract I). However, extract II was also acceptable, since tannin extraction with acetone was not significantly better than with ethanol, and the ethanol extract demonstrated greater stability. Formulations A to D were made with extract II. Even with respect to these formulations, B showed the best results for $\mathrm{pH}$ and sensory tests, and improved the formulation E. Formulation E remained stable during the rheological study, and the addition of cashew apple extract had an negative effect on its stability. Extracts I and II inhibited S. epidermidis growth. Only extract I inhibited $S$. aureus growth in the assessed concentrations. The difference observed in the antimicrobial efficacy of the extracts was probably due to their different compositions, since they were obtained with different extracting solvents

(ethanol or acetone) -- that is, with different polarities, which probably modified the composition of each extract.

The studied formulation demonstrated pseudoplastic behavior. The rheograms showed that the curves remained very close to the baseline curves; the graphs did not contain any peaks, implying that there were no instability points (Gonçalves and Maia Campos 2009). In other words, the formulations were rheologically stable.

\section{CONCLUSIONS}

In conclusion, the extracts of $A$. occidentale apples contained valuable substances for cosmetic and antimicrobial applications. The two extracts also demonstrated antimicrobial activity. However, the developed formulations still required some adjustment to improve their stability. 


\section{ACKNOWLEDGEMENTS}

The authors gratefully acknowledge the Pontifical Catholic University of Campinas and the National Council of Scientific and Technological Development (Conselho Nacional de Desenvolvimento Científico e Tecnológico) for sponsoring this study.

\section{REFERENCES}

Agostini-Costa TS, Lima A, Lima MV. Determinação de tanino em pedúnculo de caju: método da vanilina versus método do butanol ácido. Quím. Nova [online]. 2003; 6(5): 763-765.

Alcântara SR, Almeida FAC, Silva FLH, Gomes JP. Isotermas de adsorção do pedúnculo seco do caju. Rev. bras. eng. agríc. ambient.2009;13(1): 81-87.

Assunção RB, Mercadante AZ. Carotenoids and ascorbic acid composition from commercial products of cashew apple. J. Food. Comp. Anal.2003; 16(6): 647-657.

Chaves MH, Citó AMGL, Lopes JAD, et al. Fenóis totais, atividade antioxidante e constituintes químicos de extratos de Anacardium occidentale L., Anacardiaceae. Rev. bras. farmacogn. [online]. 2010; 20(1): 106-112.

Chermahini SH, Majid FAA. Cosmeceutical values, antimicrobial activities and antioxidant properties of cashew leaves extract. Afr. J. Biotechnol.2011; 10(65): 14573-14582.

Cogen AL, Nizet V, Gallo RL. Skin microbiota: a source of disease or defence? Br. J. Dermatol.2008; 158(3): 442-455.

Correa NV, Camargo JR FB, Ignacio RF, Leonardi GR. Avaliação do comportamento reológico de diferentes géis hidrofílicos. Braz. J. Pharmac. Sci.2005; 41 (1): 73-78.

Costa AF. Farmacognosia. Lisboa: Fundação Calouste Gulbenkian; 2002.

Chung KT, Wong TY, Wei CI, Huang YW, Lin Y. Tannins and human health: a review. Crit Rev Food Sci Nutr. 1998; 38(6): 421-464.

Dahake AP, Joshi VD, Joshi AB. Antimicrobial Screening of Different Extract of Anacardium occidentale Linn. Leaves. Int. J. Chem Tech Res.2009; 1(4):856-858.

Draelos ZD, Rizer RL, Trookman NS. A comparison of postprocedural wound care treatments: do antibioticbased ointments improve outcomes? J. Am. Acad. Dermatol.2011; 64(3 Suppl):S23-9.
Figueiredo RW, Lajolo FM, Alves RE, Filgueiras HAC. Physical-chemical changes in early dwarf cashew pseudofruits during development and maturation. Food Chem.2002; 77(3): 343-347.

Gonçalves GMS, Maia Campos PMBG. Shelf life and rheology of emulsions containing vitamin $\mathrm{C}$ and its derivatives. Rev Ciênc Farm Básica Apl., 2009; 30(2):217-224.

Gonçalves GMS, Srebernich SM, Souza JAM. Stability and sensory assessment of emulsions containing propolis extract and/or tocopheryl acetate. Braz. J. Pharm. Sci. 2011; 47(3): 585-592.

Hoffmann-Ribani R, Huber LS, Rodriguez-Amaya DB. Flavonols in fresh and processed Brazilian fruits. $J$. Food Comp. Anal. 2009; 22(4): 263-268.

Kalemba D, Kunicka A. Antibacterial and antifungal properties of essential oils. Curr. Med. Chem.2003; 10(10): 813-829.

Lima JR, Elizondo NJ, Bohuon P. Kinetics of ascorbic acid degradation and colour change in ground cashew apples treated at high temperatures $\left(100-180{ }^{\circ} \mathrm{C}\right)$. Int . J. Food Sci. Technol. 2010; 45(8): 1724-1731.

Melo AFM, Santos EJV, Souza LFC, Carvalho AAT, Pereira MSV, Higino JS. Atividade antimicrobiana in vitro do extrato de Anacardium occidentale L. sobre espécies de Streptococcus. Rev. bras. farmacogn. [online]. 2006; 16(2): 202-205.

Nascimento RF, Aquino FWB, Amorim AGN. A valiação do tratamento térmico na composição química e na qualidade da cajuína. Ciênc. Tecnol. Aliment. [online]. 2003; 23(2): 217-221 .

Pereira JV, Sampaio FC, Pereira MSV, Melo AFM, Higino JS, Carvalho AAT. In vitro antimicrobial activity of an extract from Anacardium occidentale Linn. on Streptococcus mitis, Streptococcus mutans and Streptococcussanguis. Odontol. Clín.-Científ. 2006; 5(2): 137-141.

Queiroz C, Lopes MLM, Fialho E, Valente-Mesquita VL. Changes in bioactive compounds and antioxidant capacity of fresh-cut cashew apple. Food Res. Int.2011; 44(5): 1459-1462.

Santos SC, Melo JCP. Taninos. In: Simões CMO. Farmacognosia: da planta ao medicamento. 5. ed. rev. Florianópolis, SC: Ed. da UFSC; Porto Alegre, RS: Ed. da UFRGS, 2003. 1102 p.

Silva JG, Souza IA, Higino JS, Siqueira-Junior JP, Pereira JV, Pereira MSV. Atividade antimicrobiana do extrato de Anacardium occidentale Linn. em amostras multiresistentes de Staphylococcus aureus. Rev. bras. farmacogn. [online]. 2007; 17(4): 572-577.

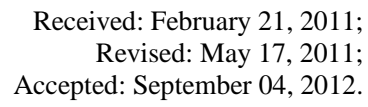

Received: February 21, 2011; Revised: May 17, 2011; Accepted: September 04, 2012. 